\title{
Impact of Cement Industry Pollution on Morphological Attributes of Wheat (Triticum Species) Kodinar Gujarat, India.
}

\author{
Sadhana Chaurasia ${ }^{1}$, Ashwani Karwariya ${ }^{2}$, Anand Dev Gupta ${ }^{3}$ \\ ${ }^{1} H O D$, Dept. of Energy and Environment, MGCGV Chitrakoot Satna MP, 485331, India \\ ${ }^{2}$ Manager- EHS, Reliance Cement Company Pvt. Ltd, Maihar Satna MP, 485331, India \\ ${ }^{3}$ Reserach Scholar, Dept. of Energy and Environment, MGCGV Chitrakoot Satna MP, 485331, India
}

\begin{abstract}
This study was aimed to know the effect of cement industry pollutants viz. $\mathrm{SO}_{2}, \mathrm{NOx}$ and PM, on morphological as well as yield characteristics of wheat (Triticum sp.) plants grown at different distance from the cement industry at Kodinar, Gujarat, India. The wheat plant near the industry showed deterioration in morphological characteristics. The study indicated that parameters reductions in wheat correlated directly with particulate pollutant which led to lower yield at more polluted site. Increased concentration of cement dust pollutant causes invisible injuries like progressive decline in photosynthetic ability and closure of leaf stomata and it affect the growth and productivity of plant. It was observed that wheat plants near the cement industry were having morphological reduction in growth and yield and as the distance from industry increases growth and yield also increases. Overall study shows that control plants were healthier in term of morphological and yield parameter. It was found that wheat plant growing near the cement industry was adversely affected.
\end{abstract}

Keywords: Air pollutants, Chlorophyll, Growth parameters and Yield.

\section{Introduction}

Now a day, cement industry caused environmental pollution problems; the pollutants of the cement industry produced the adverse impact on air, water and land. Cement industry is the one of the 17 most polluting industries listed by Central Pollution Control Board. During the last decades, the emission of dust from cement factories has been increased alarmingly due to expansion of more cement plants to meet the requirement of cement materials for construction of building. In comparison with gaseous air pollutants, many of which are readily recognized as being the cause of injure to various types of vegetation (Gupta and Mishra, 1994; Iqbal and Shafig, 2001). Relatively little known and limited studies have been carried out on the effect of cement dust pollution on the growth of plants.

Air pollution is a major problem in modern society. All combustion releases gases and particles into the air. These can include sulphur and nitrogen oxides, carbon monoxide and particulate matter, as well as smaller quantities of toxic metals, organic molecules and radioactive isotopes. Changes in the gaseous composition of earth's atmosphere due to human activities have become a prime concern for today's world (Saralabai and Vivekanandan, 1995; Prasad and Imandar, 1991). India and other developing countries have experienced a progressive degradation in air quality due to industrialization, urbanization, lack of awareness, number of motor vehicles, and use of fuels with poor environmental performance, badly maintained poor roads and ineffective environmental regulations (Prasad and Imandar, 1990; Singh and Rao, 1981).

Leaf is the plant part which is most sensitive and constantly exposed to atmosphere. The pollution indicator value of the leaf has been studied by a large number of workers. In recent past, air pollutants responsible for vegetation injury and yield losses are getting increased concern. Pollutants could be classified as either primary or secondary. Pollutants that are pumped into the atmosphere and directly pollute the air are called primary pollutants while those that are formed in the air when primary pollutants react or interact are known as secondary pollutants (Sirajuddin and Ravichandran, 2011). The pollution problem in the cement industry is dust, which is emitted from various parts of the production process such as the raw material crusher, rotary kiln, cranes, mills, storage silos and packing sections. Airborne respirable dust levels from less than 5 to more than $40 \mathrm{mg} / \mathrm{m} 3$ have been recorded in the workplace air of cement factories (Singh and Rao, 1971, 1978). Air pollution has a adverse effect on many metabolic processes in plants such as photosynthetic activities, mitochondrial respiration and stomata clogging (Shukla et al., 1990; Rajasubramanian et al., 2011). Ambient level of air pollution has been shown to affect stomata conductance, photosynthesis and root morphology of young plant. Cement factories are major source of pollutants in the study area. It was found that dust deposition affect photosynthesis, stomata functioning and productivity.

Wheat is the main Rabi crop grown in the area. Farming of wheat is also conditional due to suitability of soil as well as availability of irrigation. This results in variation of the yield between $400 \mathrm{~kg}$ and $1040 \mathrm{~kg}$ per acre. 


\section{Study area-}

The Study area was Kodinar in the Shaurashtra region of Gujrat state forms a part of a bay in the Arabian Sea. It is located approximately $30 \mathrm{~km}$. from famous temple Somnath (Veraval) on the Veraval-Una National Highway No. NH-8E. The area has co-ordinates with latitude, N 20 $54^{\prime} 45^{\prime \prime}$ and longitude, E $70^{\circ} 30^{\prime}$ 41". In this area there are total 04 cement plant units namely Ambuja Cement, Gajambuja -1, Gajambuja-2 and Siddhi Cement Ltd with capacity 2-2.5 MTPA. It is the most important industrial place.

\section{Material And Method}

The study area was confined around cement factory i.e. Ambuja cement. Wheat plant (Triticum sp.) selected for study. The plant samples were collected from various sampling stations $(0.5,1.0$ and $2.0 \mathrm{~km}$ distance from industry) and were compared with control site Pransli $20 \mathrm{~km}$ away from industry near Gir forest. At control site the cement dust deposition on the plant was almost negligible. After proper cleaning the plant, root, stem and leaves were separated and average length of root and shoot of plants were measured. Average number of leaves, branches, flowers, and seeds were also counted. The fresh and above ground wheat plant parts were dried in oven at $80^{\circ} \mathrm{C}$ for 24 hours and then weighted to estimate the biomass (gm/plant) up to 100 days at 20 days intervals. Concentration of chlorophyll was determined using the formula given by Machlachlan and Zalik, 1963.

For measuring transpiration rate, a simple photometer was devised following the standard physiological technique. For this purpose, the lower end of $25 \mathrm{ml}$ burette was attached with rubber tubing to a glass tube of 0.5 $\mathrm{cm}$ diameter and $12 \mathrm{~cm}$ length. The test plant was inserted into the open mouth of the glass tube which was then sealed with wax. The set was fixed to a stand and filled with tap water. The exposed water surface in the burette was covered with oil to check evaporation. The airtight set up was kept in sunlight for one hour and the amount of water transpired was recorded to compute the transpiration rate as $\mathrm{ml}$ water transpired/100 gm fresh plant weight/hour.

III. Result And Discussion

Table-1: Morphological parameter of Triticum species at various distances from industry in 2012.

\begin{tabular}{|c|c|c|c|c|c|c|c|c|}
\hline \multirow[t]{2}{*}{$\begin{array}{l}\text { S. } \\
\text { No. }\end{array}$} & \multirow[t]{2}{*}{$\begin{array}{l}\text { Morphological } \\
\text { Parameter }\end{array}$} & \multirow{2}{*}{$\begin{array}{c}\text { Distance } \\
\text { from } \\
\text { Industry } \\
(\mathbf{k m}) /\end{array}$} & \multicolumn{5}{|c|}{ Age in Days } & \multirow{2}{*}{ Avg. } \\
\hline & & & 20 & 40 & 60 & 80 & 100 & \\
\hline \multirow[t]{4}{*}{1.} & \multirow[t]{4}{*}{ Shoot Length (cm) } & Control & 21.8 & 41.6 & 56.3 & 66.7 & 83.2 & 53.92 \\
\hline & & 0.5 & 16.7 & 28.6 & 44.3 & 53.4 & 72.8 & 43.16 \\
\hline & & 1 & 18.3 & 31.8 & 49.6 & 56.7 & 75.2 & 46.32 \\
\hline & & 2 & 18.4 & 32.7 & 50.9 & 57.9 & 77.4 & 47.46 \\
\hline \multirow[t]{4}{*}{2.} & \multirow[t]{4}{*}{ No. of Branches } & Control & 5 & 6 & 8 & 10 & 13 & 8 \\
\hline & & 0.5 & 3 & 4 & 5 & 6 & 8 & 5 \\
\hline & & 1 & 4 & 5 & 6 & 8 & 10 & 7 \\
\hline & & 2 & 4 & 5 & 7 & 9 & 11 & 7 \\
\hline \multirow[t]{4}{*}{3.} & \multirow[t]{4}{*}{ No. of Leaf lets } & Control & 35 & 46 & 60 & 68 & 65 & 55 \\
\hline & & 0.5 & 25 & 37 & 44 & 55 & 51 & 42 \\
\hline & & 1 & 30 & 42 & 54 & 60 & 57 & 49 \\
\hline & & 2 & 33 & 45 & 56 & 65 & 61 & 52 \\
\hline \multirow[t]{4}{*}{4.} & \multirow[t]{4}{*}{ Root Length (cm) } & Control & 5.4 & 6.7 & 9.2 & 12.8 & 15.7 & 9.96 \\
\hline & & 0.5 & 3.2 & 3.7 & 5.6 & 8.85 & 11.5 & 6.57 \\
\hline & & 1 & 3.8 & 4.3 & 5.2 & 8.43 & 11.2 & 6.59 \\
\hline & & 2 & 4.6 & 5.2 & 6.2 & 9.55 & 12.5 & 7.61 \\
\hline \multirow[t]{4}{*}{5.} & \multirow[t]{4}{*}{ No. of Spike } & Control & - & - & - & 10 & 10 & 10.00 \\
\hline & & 0.5 & - & - & - & 6 & 6 & 6.00 \\
\hline & & 1 & - & - & - & 8 & 8 & 8.00 \\
\hline & & 2 & - & - & - & 9 & 9 & 9.00 \\
\hline \multirow[t]{4}{*}{6} & \multirow{4}{*}{$\begin{array}{l}\text { Wt. of } 1000 \text { grains } \\
\text { (gm) }\end{array}$} & Control & - & - & - & - & 44.2 & 44.20 \\
\hline & & 0.5 & - & - & - & - & 37.3 & 37.30 \\
\hline & & 1 & - & - & - & - & 39.4 & 39.40 \\
\hline & & 2 & - & - & - & - & 41.1 & 41.10 \\
\hline
\end{tabular}

(i) Shoot length- From the Table-1 it is evident that the shoot length was found higher avg. $53.92 \mathrm{~cm}$ in control plant. The plant growing at $0.5 \mathrm{~km}$ distance from industry have lesser growth and as the distance increases from the industry the shoot length also increases at $2 \mathrm{~km}$ distance shoot length was found higher than the plants growing at $0.5 \mathrm{~km}$ distance (Chauhan and Joshi 2010). Decrease in plant height of cowpea plant was also recorded along the gradient of air pollution by Addo et al., 2013. 
(ii) Number of branches- Number of branches has no significant difference in control and polluted site plant. The plants growing at $0.5 \mathrm{~km}$ distance from industry have minimum branches. Number of branches increased 7 at $2.0 \mathrm{~km}$ distance.

(iii) Number of leaves- Number of leaves increases as the plant goes old the maximum leaf was found in 100 days of age. At control site the number of leaf was found (Avg. 53). The number of leaf were significantly less in plants nearest to the industry as the distance from industry increases the number of leaves also increases.

(iv) Root length- From the Table-1 it is evident that the root length was found higher (Avg. 9.96) in control plant. The plant growing at $0.5 \mathrm{~km}$ distance from industry have lesser growth and as the distance increases from the industry the root length also increases at $2 \mathrm{~km}$ distance root length was found higher (Avg. $7.61 \mathrm{~cm}$ ) (Chauhan and Joshi 2010).

(v) Number of spike- Till the age of 80 days no spike were observed after 80 days maximum (10) numbers of spike was observed in control plant. The plants growing at $0.5 \mathrm{~km}$ distance were having minimum number of spike 6 . The number of spike increases as the distance of plant from industry increases.

(vi) Weight of grain-1000 oven dried seeds were weight in physical balance to determine the grain weight. Maximum weight of 1000 seeds was observed in control plant $44.20 \mathrm{gm}$. The significant reduction in grain weight $(37.30 \mathrm{gm})$ was observed in the plant growing at $0.5 \mathrm{~km}$ distance from the industry in study years (Parthasarathy et al. 1975). Grain weight also increased $(41.10 \mathrm{gm})$ at $2 \mathrm{~km}$ distance from industry. Such reduction occurs because of the reduced photosynthetic potential of dusted plant as affected by decrease absorption of light (Perice 1910). The reduction in numbers was explained due to failures of pollen grains germination on dust laden stigma and failure of fertilization (Rao, 1971; Chauhan and Joshi 2010).

\section{Dry biomass}

\section{Dry biomass of Triticum sp. root}

Dry biomass of root of Triticum sp. was observed in control and at various distances from industry in various age group of plant. The data are in given in Table-2. The average dry biomass of root in control plant was observed higher 0.16 gm in 2012, (Fig-1). The dry biomass of root increases as the age of plant increases and the distance from industry increases.

\section{Dry biomass of Triticum sp. shoot}

Dry biomass of shoot of Triticum sp. was observed in control and at various distances from industry in various age group of plant. The data are in given in Table-2. The average dry biomass of shoot in control plant was observed higher $1.45 \mathrm{gm}$ in 2012 . The dry biomass of shoot increases as the age of plant increases and the distance from industry increases (Fig-2).

Reduction in dry weight may be plant attributed to the inhibition of chlorophyll formation and damage of leaf tissue which decrease photosynthetic activity and poor plant growth apparently reduced the dry matter (Khan et al. 1982).

Table-2: Dry biomass (gm/plant) of Triticum sp. (Wheat) plant in control and industrial area 2012.

\begin{tabular}{|c|c|c|c|c|c|c|c|c|}
\hline \multirow{3}{*}{$\begin{array}{l}\text { Age } \\
\text { Plant } \\
\text { Days }\end{array}$} & \multicolumn{4}{|c|}{ Dry biomass of root } & \multicolumn{4}{|c|}{ Dry biomass of shoot } \\
\hline & \multirow{2}{*}{ Control } & \multicolumn{3}{|c|}{ Industrial area } & \multirow{2}{*}{ Control } & \multicolumn{3}{|c|}{ Industrial area } \\
\hline & & $0.5 \mathrm{~km}$ & $1.0 \mathrm{~km}$ & $2.0 \mathrm{~km}$ & & $0.5 \mathrm{~km}$ & $1.0 \mathrm{~km}$ & $2.0 \mathrm{~km}$ \\
\hline 20 & 0.10 & 0.05 & 0.08 & 0.08 & 0.15 & 0.12 & 0.12 & 0.13 \\
\hline 40 & 0.12 & 0.07 & 0.10 & 0.11 & 0.87 & 0.17 & 0.62 & 0.67 \\
\hline 60 & 0.14 & 0.10 & 0.12 & 0.12 & 1.20 & 1.01 & 0.98 & 1.24 \\
\hline 80 & 0.18 & 0.12 & 0.12 & 0.16 & 2.02 & 1.97 & 1.77 & 2.14 \\
\hline 100 & 0.26 & 0.19 & 0.19 & 0.21 & 3.01 & 2.66 & 2.54 & 2.56 \\
\hline Average & 0.16 & 0.11 & 0.12 & 0.14 & 1.45 & 1.19 & 1.21 & 1.35 \\
\hline
\end{tabular}



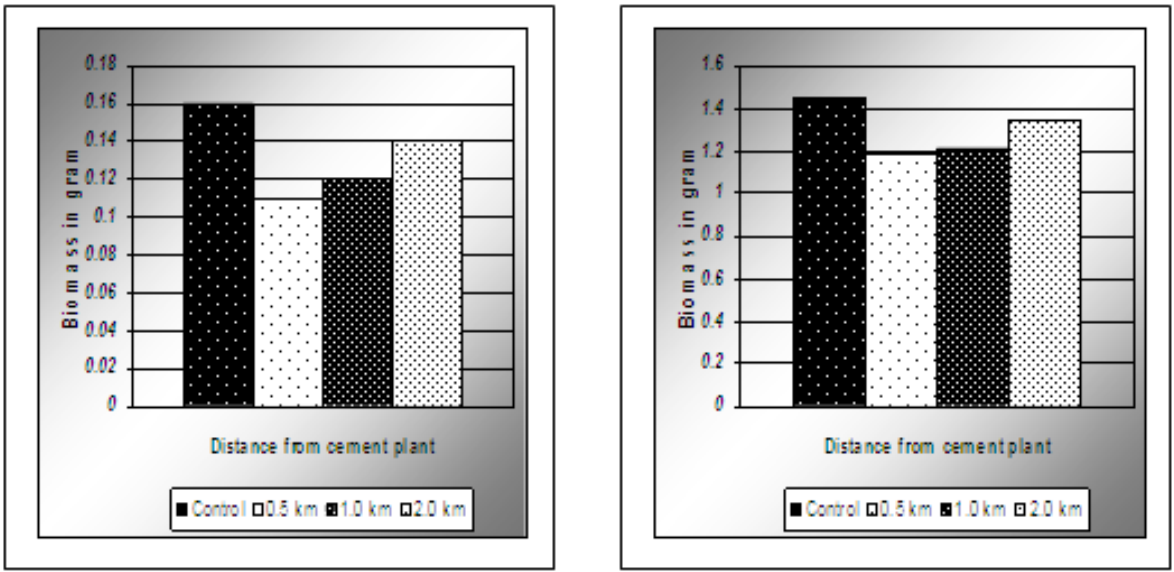

Fig-1: Average dry biomass of wheat root. Fig-2: Average dry biomass of wheat shoots.

Table-3: Transpiration rate (ml. water loss/100 $\mathrm{g}$ fresh wt./hour) of Triticum sp. (Wheat) plant in control and industrial area in 2012.

\begin{tabular}{|l|l|l|l|l|l|}
\hline S. No. & \multirow{2}{*}{$\begin{array}{l}\text { Plant age in } \\
\text { days }\end{array}$} & \multirow{2}{*}{ Control } & \multicolumn{3}{|c|}{ Distance } \\
\cline { 4 - 6 } & 20 & & $\mathbf{0 . 5} \mathbf{~ K m}$ & $\mathbf{1 . 0 0} \mathbf{~ K m}$ & $\mathbf{2 . 0 0} \mathbf{~ K m}$ \\
\hline 1. & 45.70 & 7.10 & 7.20 & 7.80 \\
\hline 2. & 40 & 17.50 & 7.80 & 8.10 & 8.80 \\
\hline 3. & 60 & 18.90 & 8.70 & 9.70 & 9.70 \\
\hline 4. & 80 & 20.20 & 9.10 & 9.90 & 10.60 \\
\hline 5. & 100 & 21.50 & 9.80 & 10.20 & 11.80 \\
\hline \multicolumn{2}{|l}{ Avg. } & $\mathbf{1 8 . 7 6}$ & $\mathbf{8 . 5 0}$ & $\mathbf{9 . 0 2}$ & $\mathbf{9 . 7 4}$ \\
\hline
\end{tabular}

Transpiration in Triticum sp.

The transpiration rate of Triticum sp. plant was observed higher in control plant 18.76 (Table-3, Fig-3). The rate of transpiration increases as the age of plant increases and the distance from industry increases at $0.5 \mathrm{~km}$ distance transpiration rate was observed 8.50 which increase 9.02 at $1 \mathrm{~km}$ distance and further increases $9.74 \mathrm{ml}$ at $2 \mathrm{~km}$ distance from industry.

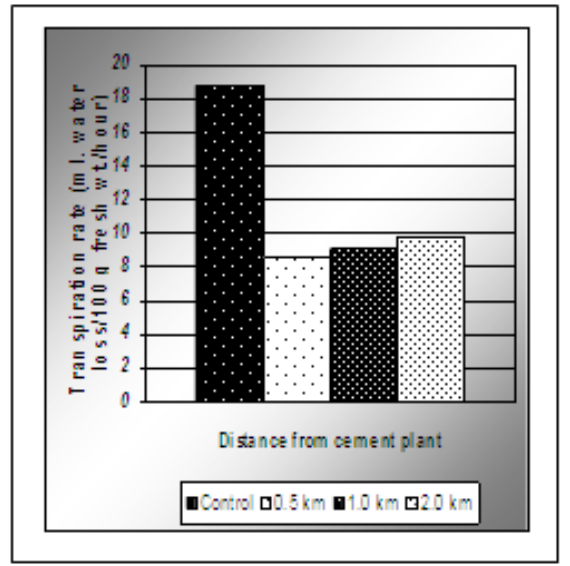

Fig-3: Average transpiration rate in wheat.

Table-4: Total chlorophyll content ( $\mathrm{mg} \mathrm{g}^{-1}$ dry wt. of leaves) of leaves on control and industrial area in 2012.

\begin{tabular}{|c|c|c|c|c|}
\hline \multirow{2}{*}{$\begin{array}{c}\text { Plant age in } \\
\text { days }\end{array}$} & \multirow{2}{*}{$\begin{array}{c}|c| \\
\text { Control }\end{array}$} & $\mathbf{0 . 5} \mathbf{~ K m}$ & $\mathbf{1 . 0 0} \mathbf{~ K m}$ & $\mathbf{2 . 0 0} \mathbf{~ K m}$ \\
\hline 20 & 2.56 & 1.1 & 1.15 & 1.18 \\
\hline 40 & 3.20 & 2.12 & 2.15 & 2.26 \\
\hline 60 & 4.12 & 2.14 & 2.18 & 2.34 \\
\hline 80 & 4.64 & 2.21 & 2.33 & 2.56 \\
\hline 100 & 4.04 & 2.08 & 2.1 & 2.15 \\
\hline Average & $\mathbf{3 . 7 1}$ & $\mathbf{1 . 9 3}$ & $\mathbf{1 . 9 8}$ & $\mathbf{2 . 0 9}$ \\
\hline
\end{tabular}




\section{Total chlorophyll in Triticum sp.}

The maximum average chlorophyll concentration was observed in control plant $3.71 \mathrm{mg} / \mathrm{gm}$ dry weight in 2012 (Table-4). The chlorophyll concentration increases as the age of plant increases and the distance from industry increases. At $0.5 \mathrm{~km}$ distance chlorophyll concentration was observed $1.93 \mathrm{mg} / \mathrm{gm}$. which increase 1.98 at $1 \mathrm{~km}$ distance and further increases 2.09 at $2 \mathrm{~km}$ distance from industry (Fig-4).

The chloroplast damaged by incorporation of cement dust on leaf caused reduction in chlorophyll concentration in the plants which are near the industry was also reported by Czaja, 1962; Lerman, 1972; Singh and Rao, 1978. The shading effect of such layer could lead to suppression of chlorophyll a synthesis (Peirce, 1910; Czaja, 1962; Bohne, 1963). The similar results were observed in maize crop (Pandey et al. 1999) and gram leaves (Pandey and Sinba 1989). These were sample of evidence concerning the detrimental effects of gaseous pollutants, such as $\mathrm{SO}_{2}$ at higher concentrations, degrades chlorophyll to a photosynthetically inactive phaeophytin and $\mathrm{Mg}^{++}$.

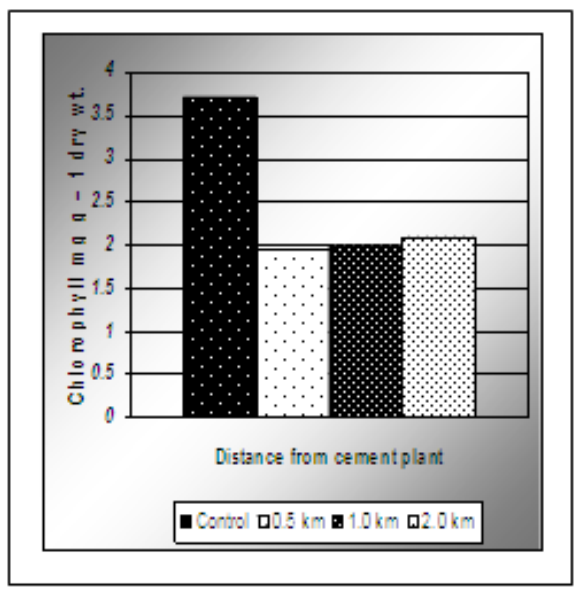

Fig-4: Chlorophyll in wheat leaves.

\section{Conclusion}

Morphological characters of Triticum sp. was studied at different distance from the industry and compared with the control plant. The data obtained at different stage of development indicate that shoot length, root length, number of branches, number of leaves, number of flower, number of seed and weight of seed were affected by cement industry pollution. The plant growing in control site were healthy than the plant growing near the cement industry. As the distance from the industry increases the plant also improves. The yield in term of seed weight regarding unpolluted plant may be attributed to the photosynthetic potential as against the dusted plant and assimilate supplies to support reproductive development and seed growth. Yield reduction was observed along the gradient of air pollution. A loss in total chlorophyll in the leaves of plants exposed in severe air pollution supports the argument that the chloroplast is the primary site of attack by air pollutants and decreases pigment content in the cells of polluted leaves. The transpiration rate, dry weight, chlorophyll content also shows the similar pattern indicating that cement factory is adversely affecting the growth and morphology of wheat plant.

\section{References}

[1]. Addo. M.A., Darko E. O., Gordon C. and Nyarko B.J.B. (2013) Contamination of soils and loss of productivity of Cowpea (Vigna unguiculata L.) caused by cement dust pollution, Inter. J. Res. In Chem. and Env. 3(1): 272-282.

[2]. Central Pollution Control Board, Central Labotratory Test Method, DOC: CB/CL/TM/9, Issue No.1: 2001

[3]. Chauhan A. and Joshi P.C. (2010) Effect of ambient air pollutants on wheat and mustard crops growing in the vicinity of urban and industrial areas, New York science J. 3(2): 52-60.

[4]. Czaja A.T. (1962) Uber das problem der zementstaubwirkungen auf Pflanzen von zementofenstaub auf pflanzen, Angew. Bot.40: 106-120.

[5]. Gupta A. K. and Mishra R.M. (1994) Effect of lime kiln's air pollution on some plant species, Pollution Research 13(1): 1-9.

[6]. Iqbal M.Z. and Shafig M. (2001) Periodical effect of cement dust pollution on the growth of some plant species. Turk. J. Bot., 25: 19-24.

[7]. Khan M.I.H., Siddiqui T.O. and Khan S. (1982) Ratio of ray and fusiform initials in some Jasminum species. Ind J. For., 5: $317-$ 318.

[8]. Lerman S. (1972) Cement kiln dust and the bean plant (Phaseolus vulgaris L. Black valentioe Var,): In depth investigations into plant morphology, physiology and pathology, Ph.D. Dissertation, University of California, Riverside.

[9]. Machlachlan S. and Zalik S. (1963) Plastid structure, chlorophyll concentration and free amino acid composition of a chlorophyll mutant of Barley, Can J. Bot, 40: 1053-1062.

[10]. Pandey D.D. and Simba A.K. (1989) Effect of cement kiln dust on chlorophyll in gram leaves. Indian J. Ecol., 16: 178-179. 
[11]. Pandey D.D., Nirala A.K. and Gaulam R.R. (1999) Impact of stone crusher dust pollution on maize crop. Indian J. Environ. Ecoplan., 2: 43-46.

[12]. Parthasarathy S., Arunachalam M., Natarajan K., Oblisami G. and Rangaswami G. (1975) Effect of cement dust pollution on certain physical parameter of maize crop and soils, Indian J. Environ. Hlth. 17: 114-120.

[13]. Peirce G.J. (1910) An effect of cement dust on orange trees. Plant World $13: 283-288$

[14]. Prasad M.S.V. and Inamdar J.A. (1990) Effect of cement kiln dust pollution on ground nut, Indian Bot Cont. 7(4):159-162.

[15]. Prasad M.S.V. and Inamdar J.A. (1991) Effect of cement kiln dust pollution on growth and yield of Vigna sp. Indian J. Ecol., 18: 91-94.

[16]. Raajasubramanian D., Sundaramoorthy P., Baskaran L., Sankar G.K., Chidambaram Al. A. and Jeganathan M. (2011) Cement dust pollution on growth and yield attributes of groundnut (Arachis hypogaea L.), International Multi. Res. J. 1 (1): 31-36.

[17]. Rao D.N. (1971) Study of the air pollution problem due to coal unloading in Varanasi, India, Proceedings of the $2^{\text {nd }}$ Inter clean air Cong. (ed), H.M. Engly and W.T. Berry. Academic Press Inc, New York, 273-276.

[18]. Saralabai V.C. and Vivekanandan M. (1995) Effect of application of cement exhaust on germination and seedling growth of legumes. Indian J. Pl. Physiol., 3: 257-259.

[19]. Shukla J., Pandey V., Singh S.N., Yunus M., Singh N. and Ahamad K.J. (1990) Effect of cement dust on the growth and yield of Brassica campestris L. Environmental Pollution, 66: 81-88.

[20]. Singh N and Rao D.N. (1981) Certain responses of wheat plants to cement dust pollution. Environ. Poll. (Ser. A.) 24: 75-81.

[21]. Singh S.N. and Rao D.N. (1978) Effect of cement dust pollution on soil properties and on wheat plants, Indian J. Environ, Health 20: $258-267$.

[22]. Sirajuddin. M. and Ravichandran M. (2010) Ambient air quality in an urban area and its effects on plants and human beings: A case study of tiruchiraalli, India. Kathmandu University Journal of Science, Engineering and Technology 6(2): 13 - 19. 